\title{
ТЕХНОЛОГІЯ ОРГАНІЗАЦІї КОМПЕТЕНТНІСНОГО ПІДХОДУ В КОНТЕКСТІ ВИЩОЇ ОСВІТИ
}

У статті обтрунтовано концептуальні підходи до розроблення технологї організаиії самостійної роботи студентівфілологів в умовах сучасної університетської освіти, інтерпретовано в прагматичний аспект види самостійної роботи в контексті дидактичного прочесу вищої иколи.

Ключові слова: технологія організаиії самостійної роботи, професійні компетенції, види самостійної роботи, формування професійних компетенцій.

В статье обоснованы концептуальные подходы к технологии организации самостоятельной работы студентовфилологов в условиях современного университетского образования, интерпретированы в практический формат видь самостоятельной работы в контексте дидактического процесса высшей школь.

Ключевые слова: технология организачии самостоятельной работы, профессиональные компетениии, виды самостоятельной работы, формирование профессиональных компетенций.

The conceptual approaches to technology of the organizing student's independent work in the modern university education are substantiated in this article. The different kinds of student's independent work in the context of the didactic process of the higher education are interpreted in a practical format.

Key words: technology of the organizing student's independent work, the formation of professional competencies.

В умовах організації навчально-виховного процесу у вищій школі за кредитно-модульною системою навчання особливо актуалізується самостійна робота студентів.

Перебудова самосвідомості студентів, розкриття механізмів саморозвитку й становлення їх індивідуальності на сучасному етапі професійної підготовки майбутнього фахівця $\epsilon$ ефективним чинником мотивації до самоосвітньої діяльності.

Проблема організації самостійної роботи студентів не $є$ новою, однак і донині активно досліджується дидактами, психологами, лінгводидактами за різними напрямками. Зокрема, у галузі психології вона пов'язується 3 розвитком закономірностей аналітико-синтетичної, дослідницької, творчої діяльності студентів, вивченням шляхів становлення їхньої пізнавальної активності (І. Бех, Л. Виготський, П. Гальперін, В. Давидов, Г. Костюк, С. Максименко, В. Семиченко, Н. Тализіна). У дидактиці обгрунтовується необхідність систематичної організації самостійної роботи, розкривається вплив інтерактивних методів і прийомів навчання на розвиток активності та самостійності студентів (А. Алексюк, Н. Бібик, В. Бондар, В. Буряк, М. Данилов, П. Підкасистий, С. Сисоєва, О. Пометун, О. Пехота).

Лінгводидакти аналізують види, форми і принципи організації самостійної роботи, визначають їі роль у формуванні професійних комунікативних компетенцій (О. Баринова, В. Бориско, О. Горошкіна, Н. Голуб, О. Любашенко, С. Ніколаєва, М. Пентилюк, О. Петращук).

Незважаючи на значний досвід, що віддзеркалює специфіку самостійної роботи і процесу формування професійних компетенцій студентів-філологів, проблема залишається недостатньо розв’язаною, оскільки на кожному етапі наукового пізнання з'являються нові аспекти їі розгляду.

Метою статmі є теоретичне обгрунтування технології організації самостійної роботи студентів в умовах сучасної університетської освіти.

Аналіз, уточнення і розроблення понятійно-термінологічного апарату є складником теоретичного осмислення будь-якої досліджуваної проблеми. Незважаючи на те, що поняття «самостійна робота» давно перебуває в науковому обігу, зміст його дискусійний. На сучасному етапі відбувається подальший розвиток досліджуваного поняття, що характеризується такими тенденціями: багатогранністю вияву дефініцій «самостійна робота», «самостійна діяльність», «самоосвіта», «саморозвиток», «самовдосконалення», «самореалізація»; наявність поряд із традиційними інноваційних підходів до розв'язання досліджуваних питань.

Так, у педагогіці термін «самостійна робота» розглядається то як «навчальне завдання», то як «індивідуальне науково-дослідницьке завдання», то як «самостійна діяльність». Сплутування змісту завдання і самого процесу діяльності дещо ускладнює уніфікацію поняття «самостійна робота».

В «Енциклопедії освіти» самостійна робота тлумачиться так: 1) діяльність індивіда, що здійснюється ним своїми власними силами без сторонньої участі; 2) спланована індивідуальна або колективна робота студентів. У навчанні «самостійна робота» є специфічною формою навчальної діяльності, що виконується за завданням і під методичним керівництвом викладача, але без його безпосередньої участі [7, с. 804].

Аналіз наукових підходів до визначення поняття «самостійна робота» показує надзвичайну різноманітність його тлумачень. Зокрема, вона розглядається вченими як:

складне, багатозначне явище [1];

цілеспрямована, активна, відносно вільна діяльність студента [3];

форма самоосвіти, пов’язана з навчальною діяльністю [2];

- $\quad$ специфічна форма навчальної діяльності студента [6]; 
- різні види індивідуальної і колективної діяльності студентів, які здійснюються ними на аудиторному і позааудиторному заняттях чи вдома за завданням без участі викладача безпосередньо [9];

правильно організована навчальна діяльність на заняттях, що мотивує самостійне іiі розширення і продовження у вільний час [11];

різновид свідомої навчальної, дослідницької й творчої діяльності, яка викликає у студентів потребу в розвитку особистісно специфічної активності розуму і виявляється в можливості логічно мислити, розв'язувати певні проблеми, інтелектуально розвиватися, готуватися до професійної діяльності, контролювати себе та самовдосконалюватися [8].

У контексті нашого дослідження прийнятним уважаємо визначення, сформульоване С. Сисоєвою, яка тлумачить самостійну роботу студента як одну 3 найважливіших складових навчального процесу, у ході якої відбувається формування навичок, умінь, знань і надалі забезпечується засвоєння студентом прийомів пізнавальної діяльності, виникає інтерес до дослідницької, наукової, творчої роботи і в результаті розвивається здатність розв'язувати проблеми професійного спрямування [10, c. $160-161]$.

У статті термін «самостійна робота» розглядається як цілеспрямована навчальна діяльність, організована самим студентом з урахування внутрішніх пізнавальних мотивів, здійснювана ним у позааудиторний час i контрольована як викладачем відповідно до вимог робочої програми, так i самим студентом через контекст завдань, визначених у картці самостійної роботи.

Вивчення й аналіз наукових джерел про специфіку самостійної роботи студентів дали змогу спроектувати модель технології організації самостійної роботи у формуванні професійних компетенцій студентів-філологів, яка враховує систему підготовки майбутнього філолога в умовах університетської освіти, поєднує зміст керованого навчання 3 органічним поєднанням різновидів самостійної роботи, iї структурних компонентів, мети і завдань, типів та сукупності педагогічних умов.

Самостійна робота студента під час навчання у вищому навчальному закладі спрямована на досягнення мети та розв'язання таких завдань:

- оволодіння навичками й уміннями самостійного опрацювання теоретичного матеріалу;

- самостійне опрацювання додаткових джерел, інтернет-ресурсу, запропонованих програмних продуктів;

- виконання творчих проектів задля розвитку самостійного пошуку нових підходів до структурування знань як засобу цілісного розуміння специфіки майбутньої професійної педагогічної діяльності.

Для того, щоб самостійна робота студента була ефективною, необхідно враховувати педагогічні умови, до яких віднесено:

- забезпечення правильного поєднання обсягів аудиторної та самостійної роботи;

- організація самоосвітньої діяльності студента під час аудиторної та позааудиторної роботи;

- забезпечення студентів належним навчально-методичним супроводом для проведення практично-семінарських, лабораторних занять та самостійної роботи;

- контроль за результатами самостійної роботи та використання раціональної системи заохочень студентів для їі якісного виконання.

Ефективність самостійної роботи, як переконує практика, значною мірою залежить від оптимального поєднання в навчальному процесі вишу усталених різновидів, виокремлених за такими критеріями:

- $\quad$ місця навчання (аудиторна, позааудиторна, домашня);

- форми навчання (денна, заочна, екстернатна, дистанційна);

- ступеня вияву самостійності (невласне самостійна, самостійна за завданням, власне самостійна); кількості учасників (фронтальна, групова, індивідуальна);

- рівня відтворення навчального матеріалу (за зразком, репродуктивно-креативна, дослідницько-пошукова, власне творча з високим ступенем самостійності);

- виду діяльності (навчальна, навчально-пізнавальна, пізнавальна, дослідницька, творча, проектна);

- ролі викладача (підготовча, консультативна, контрольно-корекційна).

Залежно від місця і часу проведення самостійної роботи студента, характеру керування нею викладачем та способів контролю за їі результатами, вона поділяється на такі види:

- самостійна робота під час проведення основних форм аудиторних занять (лекції, семінари, практичні, лабораторні заняття);

- самостійна робота під контролем викладача у формі планових консультацій, індивідуальних занять, проведення контрольно-модульних робіт, заліків та іспитів);

- позааудиторна самостійна робота під час виконання студентами домашніх завдань навчального, пошукового, дослідницького типу;

- виконання курсових, дипломних, магістерських робіт, різних видів проектів. 
Перші два види самостійної роботи студента, як зазначає С. Сисоєва, здійснюються під більшим чи меншим керівництвом викладача, останні ж два види здійснюються студентом практично повністю самостійно (керівництво викладача в такому разі неявне) [10, с. 163].

Щодо структури самостійної роботи студента зауважимо, що в ній можна виокремити два компоненти: 1) самостійна робота, організована викладачем; 2) самостійна робота, організована безпосередньо студентом.

Перший компонент самостійної роботи студента включено до навчальної діяльності для вивчення передбачених навчальним планом дисциплін, яка реалізується під час аудиторних занять або вдома самим студентом. Прикладом може бути, самостійна робота як вид контролю знань студентів.

Для формування професійних компетенцій майбутніх філологів необхідна така організація самостійної роботи, під час якої запропоновані завдання виконуються студентом абсолютно самостійно, тобто здійснюється реалізація другого компонента самостійної роботи, а контроль викладача присутній лише на проміжних етапах виконання завдань. Це, зокрема, може бути вибірковий контроль під час проведення консультацій, індивідуальних занять із метою своєчасної корекції в подальшому виконанні курсової, дипломної чи магістерської роботи, творчого проекту, презентації тощо.

Як показує практика, на перших етапах формування професійних компетенцій у студентів доцільно пропонувати завдання, опрацювання яких вимагає незначної за обсягом предметної галузі. Студентам доцільно запропонувати план, методичні рекомендації для самостійної роботи та список літератури. Результатом може слугувати доповідь, лінгвістичне повідомлення чи інформація, виступ на вільну тему. На другому етапі формування професійних компетенцій у студентів необхідно розширювати предметну галузь та здыйснювати оформлення та презентацію результату у вигляді реферату, проведення «круглого стола», семінару, конференції, ділової проектної гри. План самостійної роботи та список літератури студенти готують самостійно. На третьому етапі, який відповідає активному та креативному формуванню професійних компетенцій, самостійне здобуття знань студентів входить до складу завершальних завдань, безпосередньо пов'язаних із майбутньою професійною, виробничою та науковою діяльністю - виробнича (педагогічна активна) практика, написання курсових, дипломних чи магістерських робіт.

Отже, технологія організації самостійної роботи у формуванні професійних компетенцій майбутніх студентів-філологів передбачає використання різних форм, 3-поміж яких - самостійне виконання практичних і лабораторних завдань, підготовка доповідей, виступів, лінгвістичних повідомлень, проведення семінарів (інтуїтивний та репродуктивний рівні); проведення конференцій, «круглих столів», дискусій, презентацій (зразковий конструктивний рівень); написання та захист курсових, дипломних чи магістерських робіт, проведення практик (виробничих, асистентських), розроблення творчих проектів (активний або креативний рівень формування професійних компетенцій студентів); самостійне визначення тем, створення та розв'язання завдань для професійно-особистісного саморозвитку і самовдосконалення (усі зазначені рівні).

\section{Література}

1. Алексюк А. М. Педагогіка вищої школи. Курс лекцій: модульне навчання: [навч. посіб.] / А. М. Алексюк. - К. : ІСДО, 1993. - 220 с. 2. Болонський процес: Нормативно-правові документи / укладачі: 3. І. Тимошенко, І. Г. Оніщенко, А. М. Грехов, Ю. І. Палеха. - К. : Вид-во Європ. ун-ту, 2004. - 102 с. 3. Володько В. М. Самостійна пізнавальна діяльність студентів: [метод. рекомен.] / В. М. Володько, І. С. Дмитрик, Т. В. Іванова. К. : ІСДО, 1993. - 52 с. 4. Гончаренко С. Український педагогічний словник / С. Гончаренко. - К. : Либідь, 1997. - 376 с. 5. Журавська Л. Концептуальні умови управління самостійною роботою студентів у вищих закладах освіти / Л. Журавська // Освіта і управління. - 1999. - № 2. - С. 105-115. 6. Зязюн I. А. Неперервна освіта як основа соціального поступу // Неперервна професійна освіта: теорія і практика : [зб. наук праць : у 2-х ч.] / упор. : Степко М. Ф., Болюбаш Я. Я., Шинкарук В. Д., Грубінко Б. В., Бабин І. І. - Тернопіль : Вид-во ТНПУ імені В. Гнатюка, 2004. - 202 с. 7. Енциклопедія освіти / Акад. пед. наук України; головний редактор В. Г. Кремень. - К. : Юрінком Інтер, 2008. - 1040 с. 8. Козаков В. А. Самостоятельная работа студентов и ее информационно-методическое обеспечение / В. А. Козаков. - К. : Вища школа, 1990. 9. Пидкасистый П. И. Самостоятельная деятельность учащихся / П. И. Пидкасистый. - М. : Педагогика, 1981. - 78 с. 10. Сисоєва С. О. Інформаційна компетентність фахівця: теорія та практика формування : [навч.-метод. посіб.] / С. О. Сисоєва, Н. В. Баловсяк. - Чернівці: Технодрук, 2006. - 208 с. 11. Ужик В. О. Педагогічні основи організації самостійної роботи студентів / В. О. Ужик. - К. : Вища школа, 1981. - 23 с. 12. Філіпенко А. С. Основи наукових досліджень. Конспект лекцій : [навч. посіб.] / А. С. Філіпенко. - К. : Академвидав, 2005. $208 \mathrm{c}$. 